\title{
Nitrite in Nature: Determination with Polymeric Materials
}

\author{
Nilgün Yenil ${ }^{1}$ and Fadim Yemiș ${ }^{1 *}$ \\ ${ }^{1}$ Manisa Celal Bayar University, Sciences and Arts Faculty, Department of Chemistry, 45030, \\ Muradiye-Manisa, Turkey. \\ *Corresponding Author Email: fadimyemis@ hotmail.com \\ Received 08 November 2017, Revised 02 October 2018, Accepted 01 November 2018
}

\begin{abstract}
Nitrogen compounds being important for the vital activities of living things are produced by the nitrification process and occurred spontaneously in the nitrogen cycle. Human vital activities are also responsible for the extra nitrogen released into the atmosphere. So, both human and environmental healths are negatively affected by the increasing nitrate and nitrate amounts in water and soil. For this reason, it is aimed to ensure regular control of nitrates and nitrites at certain levels in order to protect the universe and all living things. Their precise and selective determination by various methods is very important. Their determinations can usually be made by using electrochemical, spectrophotometric, chromatographic and titrimetric methods. Nowadays instead of these techniques, sensors are preferred in determining nitrate and nitrite due to their easy, fast, selective and sensitive application properties. Furthermore, polymeric materials have shown great promise for different sensing applications such as gas, humidity, explosive and water pollutants. Sensors, which are developed by polymerization, have very high quality for the determination of nitrite. The highly sensitive results of optical and electrochemical sensors attract the attention of researchers. In this review, different detection methods for nitrite ions and various studies on the preparation of polymeric sensors that can selectively capture the nitrite ions in complex matrices are examined.
\end{abstract}

Keywords: Nitrite, Dyes, Polymer, Optical sensor, Electrochemical sensor.

\section{Introduction}

Nitrogen element, one of the fundamental components of proteins and nucleoproteins, both plays an important role in the growth of living things and forms the main mass of the atmosphere. However, nitrogen in elemental form cannot be taken directly from the atmosphere by living things. The using of atmospheric nitrogen gas by living beings can be possible through turning this gas into the inorganic form such as ammonia and nitrate via fixation. The high amount of nitrogen gas existed in the atmosphere increases the amount of nitrate in soil and water due to fixation [1]. At first glance, the use of this excess nitrate as a nutrient source by plants may suggest that it destroys the harmful effects of nitrate. However, plants that use nitrate in the production of bio- molecules such as proteins and nucleic acids transmit excess nitrate to all living things as part of the nutritional chain and cause toxic effects [2].

Every living thing produces a certain amount of waste in the food chain and dies eventually. All wastes generated by the nutrition or deaths of living things are decomposed by the denitrification bacteria in the soil [1]. In this way, existing nitrite or nitrate is converted into nitrogen gas and released into the atmosphere. This cycle, which involves the conversion of ions and molecules such as nitrogen gas, ammonia, nitrite and nitrate into one another, is known as the nitrogen cycle [3]. This nitrogen cycle is shown in Fig. 1 [4]. 
In the nitrogen cycle, elemental nitrogen first transforms into ammonia. The resulting ammonia turns into nitrate via nitrite by a two-step process [5]. This is called nitrification. The first step in nitrification is related with the transformation of ammonia into nitrite in the aerobic environment which is catalyzed by nitrosomonas bacteria. The second step is responsible for the nitrobacteria catalyzed nitritenitrate transformation. The reverse version of this event is known as denitrification [6]. The equations for nitrification and denitrification (equilibrium 1 and 2) in the nitrogen cycle are shown as follows [7];

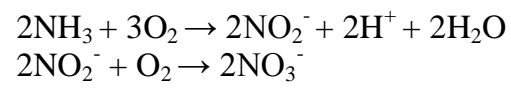

equilibrium 1 equilibrium 2

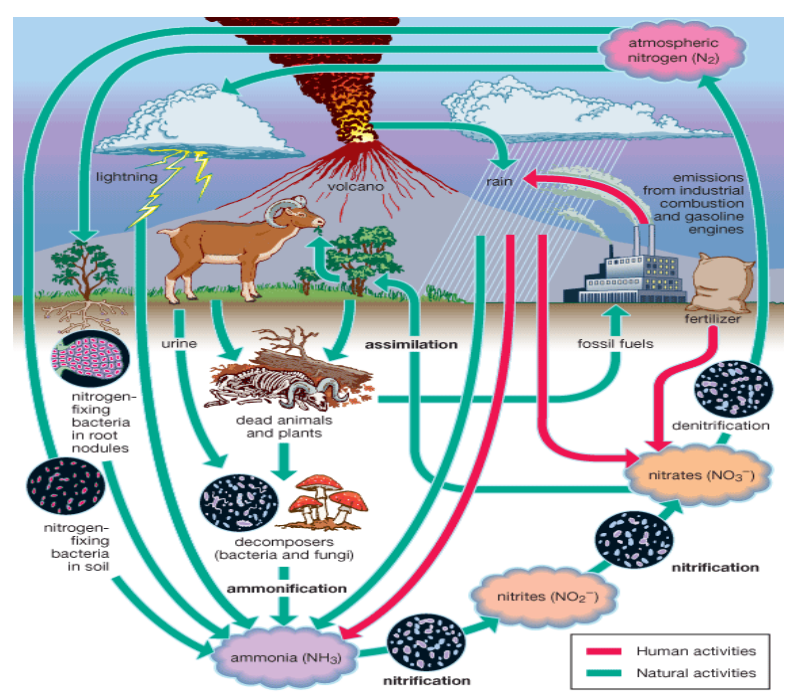

Figure 1. Nitrogen cycle

When the nitrite and nitrate ions obtained from these equations are compared, it has been reported that the chemical stability of nitrite ion is less than nitrate ion. Because there is scientific evidence stating that nitrite ions rapidly oxidize to nitrate ions and very rarely have excessive concentrations in surface waters. It is known that the labile structure of nitrite ion $\left(\mathrm{NO}_{2}{ }^{-}\right)$originates from $\mathrm{N}^{+3}$. Nitrite tends to form strong complexes with a large number of transition metals due to its labile structure. Nitrite and its complexes form are found in the groundwater in low concentrations; as a result, they do not cause serious problems in terms of environment. According to the literature, nitrite concentration in the nature is approximately in the level of $1.0 \mathrm{mg} / \mathrm{L}$ which is $1-5 \%$ of the nitrate concentration [8]. The excessive fertilization of vegetables causes nitrate accumulation in them. In addition to the use of nitrogenous fertilizers, pesticides and chemical industry wastes are also the main sources of nitrate accumulation. Therefore, nitrate/nitrite accumulation is not only seen in plants but also seen in the water resources. It is reported that the amount of nitrate transferred to human body through consumption of vegetables is approximately $87 \%$ [9]. Nitrite is also used as an antimicrobial food additive, because of its properties such as supporting the color stability and increasing the aroma, showing the resistance against the bacteria and inhibiting the formation of oxidation products [10]. Nitrite, a toxic substance that is allowed to exist in foods as an additive, is widely used in meat and related products, cheese, fruit juices, and natural mineral water and fruity mineral waters [9]. Thus, the use of it means that there is an excessive nitrite loading in the human body.

On the contrary, nitrate ions which can be taken from many sources to the human body do not have direct toxic effects like nitrite ions. However, while a certain amount of the nitrate taken through food are partially degraded by bacteria existing in oral cavity and forming mouth flora into nitrite, the rest of the nitrate goes into gastro-intestinal system and gets into circulation [2]. Via salivary glands, they are excreted into oral cavity again and they continue to be degraded into nitrite [11]. The formed nitrite by this way interacts with hemoglobin and transforms into methemoglobin. As a result, by oxidizing $\mathrm{Fe}^{+2}$ ions in the hemoglobin, they become $\mathrm{Fe}^{+3}$ ions and the duty of blood about carrying oxygen is prevented. Asphyxiation and dyspnea are observed in this health problem in which the color of blood turns into a color resembling chocolate. This problem which is known as blue baby syndrome or methemoglobinemia is quite dangerous in infants. Because enzymes to eliminate nitrate in the digestive system of babies are not developed and powder products obtained from nitrate-bearing whey are not appropriate for use as infant foods [2, $12,13]$. Another toxic effect of nitrite is that it turns into nitrosamine derivative with any 
secondary amine $[2,12,14]$. Bacteria, $\mathrm{pH}$ of the environment, temperature and physiological conditions are important in the formation of nitrosamines. The gastric flora which enables these conditions is an appropriate environment for forming nitrosamines. It is already mentioned in the literature that potentially carcinogenic, mutagenic and teratogenic effects of nitrosamines exist [15].

\section{Nitrite determination methods}

Nitrite that is formed during biodegradation of nitrate affects human health, seriously. Therefore, the amount of nitrite determination in food, water and soil is significant. The determination of nitrite must be rapid, selective and sensitive. When the literature is analyzed, there are many analytically defined methods that are listed in Table 1 for the determination of nitrite such as titrimetric [16], spectroscopic [17-22], chromatographic [23-25] and electrochemical techniques [10, 15, 26-30]. Most of these determination methods, today, have left their place to more modern applications. Optic and electrochemical sensors are the equipment that is used in the modern nitrite determination methods.

Table 1. Summary of nitrite determination methods.

\begin{tabular}{|c|c|c|c|c|c|c|}
\hline Detection Method & Equipment & Technique & $\begin{array}{l}\text { Linear } \\
\text { Detection } \\
\text { Range }^{*}\end{array}$ & LOD $^{\ddagger}$ & $\begin{array}{l}\text { Real Sample } \\
\text { Application }\end{array}$ & Ref. \\
\hline Electrochemical & $\begin{array}{l}\text { Glassy carbon electrode modified } \\
\text { with CdTe quantum dots, } \\
\text { cetyltrimethylammonium bromide, } \\
\text { chitosan and multiwalled carbon } \\
\text { nanotubes nanocomposite }\end{array}$ & $\begin{array}{c}\text { Cyclic voltammetry } \\
\text { and } \\
\text { Square wave } \\
\text { voltammetry }\end{array}$ & $\begin{array}{l}1-100 \\
\text { and } \\
100-600^{\mathrm{a}}\end{array}$ & $0.30^{\mathrm{a}}$ & Vegetable samples & [31] \\
\hline Electrochemical & $\begin{array}{c}\text { Au electrode modified with Pt } \\
\text { nanoparticles and poly(2- } \\
\text { aminothiophenol) }\end{array}$ & $\begin{array}{l}\text { Cyclic voltammetry, } \\
\text { Chronoamperometry } \\
\text { and } \\
\text { Differential pulse } \\
\text { voltammetry }\end{array}$ & $3-1000^{\mathrm{a}}$ & $1^{\mathrm{a}}$ & Sausage samples & [32] \\
\hline Electrochemical & $\begin{array}{c}\text { Glassy carbon modified with } \\
\text { cytochrome } \mathrm{c} \text {, titanium nitride } \\
\text { nanoparticles and multi-walled } \\
\text { carbon nanotube }\end{array}$ & $\begin{array}{l}\text { Cyclic voltammetry, } \\
\text { Chronoamperometry } \\
\text { and } \\
\text { Amperometry }\end{array}$ & $1-2000^{\mathrm{a}}$ & $0.0014^{\mathrm{a}}$ & Tap and Sea water & [33] \\
\hline Electrochemical & $\begin{array}{l}\text { Glassy carbon electrode modified } \\
\text { with gold nanoparticle and } \\
\text { graphene oxide }\end{array}$ & $\begin{array}{l}\text { Cyclic voltammetry, } \\
\text { chronoamperometry } \\
\text { and } \\
\text { Amperometry }\end{array}$ & $5-2600^{\mathrm{a}}$ & $0.5^{\mathrm{a}}$ & Tap water & [34] \\
\hline Electrochemical & $\begin{array}{c}\text { Glassy carbon electrode modified } \\
\text { with carbon dots and gold } \\
\text { nanoparticles }\end{array}$ & $\begin{array}{l}\text { Cyclic voltammetry } \\
\text { and } \\
\text { Amperometry }\end{array}$ & $0.1-2000^{\mathrm{a}}$ & $0.06^{\mathrm{a}}$ & Lake water & [35] \\
\hline Titration & E-104 electrode & Chronopotentiometry & $1.3-1000^{\mathrm{b} 1}$ & $0.4^{\mathrm{b}}$ & $\begin{array}{l}\text { Underground, } \\
\text { drinking and surface } \\
\text { water samples }\end{array}$ & [36] \\
\hline Titration & Glassy carbon electrode & $\begin{array}{c}\text { Amperometry } \\
\text { and Chemiluminometry }\end{array}$ & $\begin{array}{l}0.25-65 \\
\text { and } \\
0.10-50^{\mathrm{b} 2}\end{array}$ & - & Tap and river water & [37] \\
\hline Chromatographic & UV detector & HPLC-UV & $10-1000^{\mathrm{cl}}$ & $1^{\mathrm{cl}}$ & $\begin{array}{l}\text { Blood and urine } \\
\text { samples }\end{array}$ & [38] \\
\hline Chromatographic & $\begin{array}{l}\text { Mass spectrometry and fluorescence } \\
\text { detector }\end{array}$ & $\begin{array}{l}\text { GC-MS } \\
\text { and } \\
\text { LC-FL }\end{array}$ & $2.5-100^{\mathrm{c} 2}$ & $\begin{array}{c}0.02 \\
\text { and } \\
0.29^{\mathrm{c} 2}\end{array}$ & $\begin{array}{l}\text { Biological, food and } \\
\text { environmental } \\
\text { samples }\end{array}$ & [39] \\
\hline Chromatographic & UV detector & Ion-pair HPLC & $10.0-100^{\mathrm{c} 3}$ & $10^{\mathrm{c} 3}$ & $\begin{array}{l}\text { Dew, rain, snow and } \\
\text { lake water }\end{array}$ & [40] \\
\hline Spectrophotometric & - & Spectrofluorimetry & $0.04-0.8^{\mathrm{d} l}$ & $13.6^{\mathrm{d}}$ & $\begin{array}{l}\text { water, sausage and } \\
\text { soil samples }\end{array}$ & [41] \\
\hline Spectrophotometric & - & $\begin{array}{l}\text { UV-Vis } \\
\text { spectrophotometry }\end{array}$ & $5.0-300.0^{\mathrm{d} 2}$ & $0.4^{\mathrm{d}}$ & $\begin{array}{l}\text { Water, vegetable and } \\
\text { meat product } \\
\text { samples }\end{array}$ & [42] \\
\hline
\end{tabular}

*a ( $\mu \mathrm{mol} / \mathrm{L}) ; * \mathrm{~b} 1(\mu \mathrm{g} / \mathrm{L}) ; \mathrm{b} 2(\mu \mathrm{mol} / \mathrm{L}) ; \mathrm{c} 1(\mathrm{ng} / \mathrm{mL}) ; \mathrm{c} 2(\mathrm{pg} / \mathrm{mL}) ; \mathrm{c} 3(\mu \mathrm{g} / \mathrm{L}-\mathrm{mg} / \mathrm{L}) ; \mathrm{d} 1(\mu \mathrm{g} / \mathrm{mL}) ; \mathrm{d} 2(\mathrm{ng} / \mathrm{mL})$

$\mathrm{a}(\mu \mathrm{mol} / \mathrm{L}) ; \mathrm{b} 1(0.4 \mu \mathrm{g} / \mathrm{L}) ; \mathrm{c} 1(\mathrm{ng} / \mathrm{mL}) ; \mathrm{c} 2(\mathrm{pg} / \mathrm{mL}) ; \mathrm{c} 3(\mu \mathrm{g} / \mathrm{L}) ; \mathrm{d}(\mathrm{ng} / \mathrm{mL})$ 
These nitrite determination methods given in Table 1 are either sensitive or not selective. Also, they are both expensive and time consuming. In addition, many of them that cause the formation of harmful waste require more sub-equipment.

If it respectively needs to compare these techniques, electrochemical techniques that give very sensitive and reproducibility results are cheap, fast and easy to apply techniques. In fact, modifying the electrodes used in these techniques with various substances or polymers becomes more selective while increasing the sensitivity. In other words, modified electrodes have good sensor properties. However, these some of the modified electrodes have a higher oxidation potential in the oxidation of nitrite and also limitations such as low sensitivity and narrow working ranges. As for the titrimetric method, the reagent is added to the medium as volumetric but the measurements are performed spectrophotometrically and electrochemically. These methods can be timeconsuming. There can also be problems in selectivity and repeatability for these methods.

On the other hand, the chromatographic techniques with the highest expensive equipment such as different detectors and columns give sensitive and reproducible results. And, the chromatographic techniques except the ion chromatography need to preconcentration and separation for sensitive determination of nitrite ions in the presence of the other ions.

Spectrophotometric methods are both simple and fast and do not require expensive equipment. The use of colored complexes with the substance to be determined in these methods increases their sensitivity level. However, other ions and substances may have interference effects in the determination method.

\section{Traditional methods used in the determination of nitrite}

The traditional methods for determining nitrite are spectrophotometric methods. Spectrophotometric nitrite analyses are based on the analysis method developed by Griess and Ilosvay in 1941. The main aim of this method is measurement of wave length of azo-dye which is formed by the reaction of 1-naphthylamine with diazonium salt, formed by the reaction of sulphanilic acid with nitrous acid (Figure 2A) [43]. This orange-red colored compound gives maximum absorbance value at $520 \mathrm{~nm}$ wave length. Today, most of the nitrite analysis methods use Strickland and Parsons Method which was derived from Griess-Ilosvay Method. In this method, the spectrophotometric measurement of azo-dye obtained from the reaction of $\mathrm{N}$-(1naphtyl)-ethylenediamine with diazonium salt, formed by the reaction of the nitrite and sulphanilamide in the acidic environment, is carried out (Fig. 2B) [44].

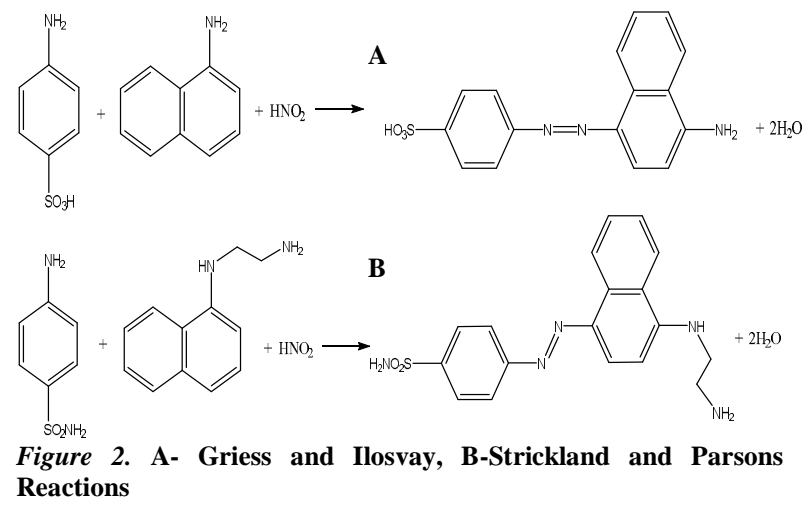

Also, automatic analysis system is developed for the analysis of nitrite ions by Grasshoff et al., based on Strickland and Parsons Method. In this method, in the first step there are the formation of a secondary aromatic amine which is the product of an aromatic amine and nitrite and obtaining an azo-compound as a result of the reaction given by this by-product and an appropriate diazonium compound. This violetcolored compound gives maximum absorbance value at $540 \mathrm{~nm}$ wave length [45]. As the reactive substances used in this method are cancerogenic, they adversely affect human health and environment. Therefore, research related to development of new methods has increased nowadays.

\section{Sensors used in the determination of nitrite}

Today, various sensors developed instead of traditional determination methods in nitrite determination are preferred. These sensors having cost less at the same time are optical (optode) [46] and electrochemical sensors [47]. 


\section{Optical (optode) sensors}

Optical sensors whose sensor part is organic or inorganic dye are prepared by immobilizing the dye on solid matrix and they provide a more eco-friendly usage. The preparation of the sensors is carried out at two steps. The first step is to mix the dye in the solvent with a straight chain polymer and plasticizer. As a result of sufficient mixing, a colored but transparent solution is obtained. The second step is to spread this transparent solution on the matrix and to evaporate the solvent from the matrix surface obtaining a transparent membrane. The optical sensors prepared by this way can easily catch the ions which they are sensitive in aqueous mediums. The sensors give sensitive and selective results for the different substances depending on the functional groups of the immobilized dyes [48-50].

Ensafi et al., prepared a low-cost optical sensor by the immobilization of the hydrolyzed dye "Safranine O" to triacetyl cellulose. They used reactive substances, being cheap, non-toxic and easily available, for the activity of the cellulose support. The researchers found that the prepared membrane is stable more than 12 months and its response time is less than 8 seconds. It is reported that the sensor gives linear response in the range of $5 \times 10^{-3}-2.00 \mathrm{mg} / \mathrm{L}$ and its detection limit is $1 \mu \mathrm{g} / \mathrm{L}$. It is reported that the prepared sensor provides good results at the nitrite determinations in sausage, flour and environmental water samples by using absorbance changes of the sensor against the increasing nitrite concentrations and is reliable when compared to standard methods [51]. Another similar research is about preparing of optical sensor by immobilization of organic dye "Gallocyanine" onto the cellulose acetate film. It is reported that the prepared membranes are stable more than six months and respond in less than seven seconds. Their linear responses are also in the range of $8 \times 10^{-3}-1.5 \mu \mathrm{g} / \mathrm{mL}$ [52].

On the other hand, Dhaoui et al., produced thin Sulfamic acid-doped polyaniline (PANI-SFA) films on the quartz surface by chemical polymerization with using ammonium peroxydisulfate as oxidizing agent and used them as optical sensors. The specific property of PANISFA is that it is active against nitrite anions and causes significant damping in the UV-vis-NIR spectra by decreasing the conductivity. Its determination limit was reported as $10^{-6} \mathrm{~mol} / \mathrm{L}$ [53].

Vallvey et al., developed an optical sensor used as test strip. This sensor was prepared by immobilizing the solution mixture of sulphonamide and $\mathrm{N}$-(1-naphthyl)ethylenediamine dissolved in nafion to mylar type polyester film. The absorbance values of this sensor was measured by dipping it into the acidified sample solution containing nitrite (at $\mathrm{pH}=2$ ). The linear response range of the method depends on the equilibrium time of the test strips with the sample solutions. The researchers concluded that the equilibrium time of test strip was 60 minutes, its detection limit was $1.4 \mu \mathrm{g} / \mathrm{L}$ and its linear response range was 4.7-200 $\mu \mathrm{g} / \mathrm{L}$ [54].

A new optical microsensor was prepared for nitrite ion by Noor et al., in 2016. In the preparation of the microsensors, self-adhesive poly(n-butyl acrylate) microspheres were synthesized by UV photocuring and Safranin O dyes was immobilized onto the spheres physically. The response of the microsensors to nitrite ions was measured by using a reflectance spectrophotometer (at $\mathrm{pH}=1$ ). It is reported that the sensor gives linear response in the range of 10$100 \mathrm{mg} / \mathrm{L}$ and its detection limit is $3 \mathrm{mg} / \mathrm{L}$. In addition, the response time of the sensor for nitrite ions is 3 minutes [55].

In another study conducted by Abdukayum and Tuerhong for the determination of nitrite, Phenosafranine dye doped sol-gel films were prepared with using sol-gel method. The prepared films were spread out over microscope slide glass as a thin film by helping of spin-coating technique. As a result of the reaction between the Phenosafranine doped sol-gel film and the nitrite ions, the absorbance values of the sol-gel films decreased and the quantity of nitrite ions was determined by this decreasing. The linear response of sol-gel films for nitrite ions was in the range of $0.1-1000 \mathrm{mg} / \mathrm{L}$ and the detection limit for nitrite was found as $9 \mu \mathrm{g} / \mathrm{L}$ [56]. The linear detection ranges and the detection limits of the optical sensors, described in the section 2.2.1, are given in Table 2 with their related references. 
Table 2. Summary of nitrite determinations with optical sensors.

\begin{tabular}{|c|c|c|c|c|}
\hline Optical Sensor & $\begin{array}{l}\text { Linear Detection } \\
\text { Range }^{*}\end{array}$ & $\mathbf{L O D}^{\ddagger}$ & Real Sample Application & Ref \\
\hline Safranine O immobilized triacetyl cellulose & $5 \times 10^{-3}-2.00^{\mathrm{a}}$ & $1^{\mathrm{a}}$ & $\begin{array}{l}\text { Beef sausage, flour and environmental } \\
\text { water samples }\end{array}$ & [51] \\
\hline Gallocyanine immobilized cellulose acetate & $8 \times 10^{-3}-1.5^{b}$ & $1^{b}$ & $\begin{array}{l}\text { Beef sausage, flour and environmental } \\
\text { water samples }\end{array}$ & [52] \\
\hline Sulfamic acid-doped polyaniline film & $10^{-6}-10^{-2 \mathrm{c}}$ & $10^{-6 \mathrm{c}}$ & - & [53] \\
\hline $\begin{array}{l}\text { Sulphonamide and N-(1-naphthyl)ethylenediamine } \\
\text { immobilized mylar film }\end{array}$ & $4.7-200^{\mathrm{b}}$ & $1.4^{\mathrm{a}}$ & $\begin{array}{l}\text { Spring, mineral, tap, well, and sea } \\
\text { water samples }\end{array}$ & [54] \\
\hline $\begin{array}{l}\text { Safranin O immobilized poly (n-butyl acrylate) } \\
\text { microspheres }\end{array}$ & $10-100^{\mathrm{a}}$ & $3^{\mathrm{d}}$ & Edible bird's nest & [55] \\
\hline Phenosafranine doped sol-gel films & $0.1-1000^{\mathrm{a}}$ & $9^{a}$ & Water samples & {$[56]$} \\
\hline
\end{tabular}

${ }^{*} \mathrm{a}(\mathrm{mg} / \mathrm{L}) ; \mathrm{b}(\mu \mathrm{g} / \mathrm{L}) ; \mathrm{c}(\mathrm{mol} / \mathrm{L}) ;{ }^{\ddagger} \mathrm{a}(\mu \mathrm{g} / \mathrm{L}) ; \mathrm{b}(\mathrm{ng} / \mathrm{mL}) ; \mathrm{c}(\mathrm{mol} / \mathrm{L}) ; \mathrm{d}(\mathrm{mg} / \mathrm{L})$

When the studies on optical sensors are examined, they are quite impressive because of their advantages such as practicality, cheapness, stability, sensitivity, selectivity and speed. However, the thickness of the films spread on the solid support matrix during the preparation of the optical sensor is important. Films should always be of the same thickness. If the same thickness is not achieved in the films, repeatability is reduced. In addition, several ions may sometimes have interference effects in optical sensors. Therefore, it is also essential to check how much interference effect the various ions have with optical sensors. Another disadvantage can be the dye leaching in assays carried out in excessively basic solutions. Nevertheless, when compared to the other spectrophotometric methods, the use of organic dyes that form colored complexes with the substances to be determined in optical sensors increases the sensitivity and selectivity levels.

\section{Electrochemical sensors}

Electrochemical sensors can be prepared by modifying electrodes with appropriate organic compounds. Like optical sensors, electrochemical sensors are also advantageous because they are easy to produce, small in size and selective. In addition, the determinations done with them give rapid, easy, sensitive and selective results $[57,58]$. For instance, in the nitrite determination method done with a modified electrochemical sensor, it was reported that nitrate ions did not interfere for nitrite [59].
The electrode in the electrochemical methods is the part where the measurement is carried out and the sensitivity and selectivity of the method depends on it. Although many electrodes can be used in electrochemical techniques, modifying the electrodes increase sensitivity and selectivity.

If the organic compound used to modify the electrode has capability to polymerization, it is polymerized on the electrode surface by applying a potential. This event which is carried out with cyclic voltammetry method is called electropolymerization. In this method, the coating thickness of the polymer can be controlled by the number of cycles $[60,61]$. However, if the organic compound does not have the property of polymerization, the compound is dissolved in a suitable solvent together with an electrically conductive polymer and the solution obtained is dripped onto the electrode surface. Afterwards, the electrode is rotated rapidly to ensure homogeneous coating of its surface, and the modification of its surface is complete with the evaporation of the solvent [62]. In the coating of the electrode surface with spinning, the control of the polymer thickness is adjusted by the spinning speed of the electrode.

In a study carried out by Wen and Kang, the surface of glassy carbon electrode (GCE) was coated with nickel tetraamino-phthalocyanine polymeric film and the electrochemical sensor, obtained, was used in the amperometric determination of nitrite. The process of coating electrode surface with electro-polymerization was 
carried out in a solution containing nickel tetraamino-phthalocyanine monomer. In the nitrite ion determination with the electrode coated with polymeric nickel tetraamino-phthalocyanine, its detection limit and linear range were reported as $1.0 \times 10^{-7} \mathrm{M}$ and $5.0 \times 10^{-7}-8.0 \times 10^{-3} \mathrm{M}$, respectively [26].

In another study carried out by Zhang et al., GCE surface was coated with aniline by electropolymerization at a suitable and constant potential. After that, copper nanoparticles were accumulated by applying a potential on the electrode surface coated with polyaniline. For the nitrite ion determination under the conditions optimized by the polyaniline- $\mathrm{Cu}$ compositemodified GCE, the determination limit and linear range were reported as $0.025 \mu \mathrm{M}$ and $0.049-70.0$ $\mu \mathrm{M}$, respectively [63].

Another electrochemical sensor for the determination of nitrite was developed by Wang et al.. The surface of GCEs was coated with "Rodamin B" dye by electropolymerization in a solution containing the dye in order to develop a new sensor sensitive to nitrite. The linear range of the response given to nitrite ion by the GCE coated with Rodamin B film was found as $0.5 \mu \mathrm{M}-7.0$ $\mathrm{mM}$ and its detection limit was $0.1 \mu \mathrm{M}$ [64].

Gligor and Walcarius developed a GCE modified with poly(Toluidine Blue $\mathrm{O}$ ) and singlewalled carbon nanotubes for amperometric determination of nitrite as electrochemical sensor. The GCE was coated with the [poly(Toluidine Blue $\mathrm{O})$ ] polymer film via electropolymerization in a solution including "Toluidine Blue O". Then, they immobilized the single-walled carbon nanotubes onto the electrode surface. The amount of nitrite was measured by using amperometric method with the modified electrode prepared in this way. And it was seen that it gave linear response in the range of $0.001-4 \mathrm{mM}$. The detection limit of the sensor in the waste water was reported as $0.37 \mu \mathrm{M}[65]$.

Peng et al. also prepared a modified GCE with copper (II) metal-organic gels (MOG) and used it for the determination of nitrite. For this purpose, its solvent was evaporated after the MOG was prepared in solvent. Then MOG was dispersed with water and dripped on to the electrode surface. The electrode surface was dried in an oven and used for nitrite determination. Nitrite concentrations in the range of $2-150 \mu \mathrm{M}$ were linearly determined and the detection limit of electrode for nitrite ion was $0.86 \mu \mathrm{M}$ [66].

In a study by Yang et al., the surface of the GCE was coated by Brilliant cresyl blue dye via electropolymerization and the electrode coated with the conductive polymer film was obtained. The obtained electrode was used as an amperometric sensor for nitrite determination and its linear response to nitrite ions was found in the range of $9 \times 10^{-7}-1.49 \times 10^{-5} \mathrm{~mol} / \mathrm{L}$. Its detection limit was $1.0 \times 10^{-7} \mathrm{~mol} / \mathrm{L}$ [67]. The linear detection ranges and detection limits of the modified electrochemical sensors, described in the section 2.2.2., are given in Table 3 with their related references.

Table 3. Summary of Nitrite determinations with electrochemical sensors.

\begin{tabular}{|c|c|c|c|c|}
\hline Electrochemical Sensor & $\begin{array}{l}\text { Linear Detection } \\
\text { Range }^{*}\end{array}$ & LOD $^{\ddagger}$ & Real Sample Application & Ref \\
\hline $\begin{array}{l}\text { Nickel tetraamino-phthalocyanine polymeric film modified } \\
\text { GCE }\end{array}$ & $5.0 \times 10^{-7}-8.0 \times 10^{-3 a}$ & $1.0 \times 10^{-7 \mathrm{a}}$ & Water samples & [26] \\
\hline Polyaniline and copper modified GCE & $0.049-70.0^{\mathrm{b}}$ & $0.025^{\mathrm{b}}$ & - & [63] \\
\hline Rodamin B film modified GCE & $0.5 \mu \mathrm{M}-7.0^{\mathrm{c}}$ & $0.1^{\mathrm{b}}$ & - & [64] \\
\hline $\begin{array}{l}\text { Poly(Toluidine Blue O) film and single-walled carbon } \\
\text { nanotube modified GCE }\end{array}$ & $0.001-4^{\mathrm{c}}$ & $0.37^{\mathrm{b}}$ & Wastewater sample & [65] \\
\hline Copper (II) metal-organic gels modified GCE & $2-150^{\mathrm{b}}$ & $0.86^{\mathrm{b}}$ & Sausage samples & [66] \\
\hline Brilliant cresyl blue modified GCE & $9 \times 10^{-7}-1.49 \times 10^{-5 a}$ & $1.0 \times 10^{-7}$ a & $\begin{array}{l}\text { Sausage and pickled vegetable } \\
\text { samples }\end{array}$ & [67] \\
\hline
\end{tabular}


In the electrochemical methods, even if no modified electrodes are used, sensitive results are obtained. However, with the modification of the electrode, the sensitivity and selectivity increase considerably. Even these electrodes provide simultaneous assays for the analysis of various ions. The film thickness is also important in these sensors. In order to obtain reproducible results, the drop size of the coating solution, dripped on the electrode surface, or the number of cycle at cyclic voltammetry should be checked when coating it. However, the electrochemical techniques using the modified electrodes are highly selective and sensitive according to the other electrochemical techniques combined with bare electrodes.

\section{Conclusion and outlook}

Nitrite has a quite active structure as a result of its lack of oxygen and tends to form harmful compounds rapidly in a living organism. Although the amount of nitrite in nature is very low, the total amount of nitrite taken into the body in several ways each day is increasing. So, it is very important to determine the amount of nitrite accurately. The present review highlights the state of art on polymers along with their modification for applications in sensing of nitrite. The synthetic routes adopted during the course of scientific innovations are compiled along with their significant parameters. Many methods developed in the determination of nitrite have high sensitivity and selectivity. However, polymeric sensors are notable for the easy, rapid, selective, precise and economic detection of nitrites. They are used as quantitative analysis devices in various industrial fields.

In determination with optical and electrochemical polymeric sensors, the functional groups of organic compounds having selective layers are important to capture target nitrite ions. They are prepared either by polymerization of the appropriate organic compounds or by the immobilizing of organic compounds in an appropriate polymer. As a summary, these both sensors can detect nitrite even in nitrate-containing solutions. Moreover, nitrite and nitrate can be detected as simultaneous and independent of one another in a single measurement in the electrochemical sensors. So far, a lot of work has been done on polymeric sensors. In the near future, we hope many harmful ions or molecules will be immediately measured using polymeric sensors. The miniaturization of polymeric sensors will lead to on spot determination of food ingredients and water in a few seconds by common person with the devices they can carry in their pockets.

\section{References}

1. C. C. Delwiche, Scientific American, 223 (1970) 136.

http://www.jstor.org/stable/24925899?seq=1 \#page scan tab contents

2. P. Santamaria, J. Sci. Food. Agric., 86 (2006) 10.

http://onlinelibrary.wiley.com/doi/10.1002/js fa.2351/epdf

3. A. R. Mosier, J. K. Syers and J. R. Freney, Agriculture and the Nitrogen Cycle Assessing the Impacts of Fertilizer Use on Food Production and the Environment, Island Press, Washington (2004).

https://kids.britannica.com/students/article/ni trogen-cycle/623550

4. M. A. Mirza, M. Y. Khuhawar and A. J. Kandhro, Pak. J. Anal. Environ. Chem., 6 (2005) 72.

http://pjaec.pk/index.php/pjaec/article/view/1 $\underline{19}$

5. Y. Peng and G. Zhu, Appl. Microbiol. Biotechnol., 73 (2006) 15. doi: 10.1007/s00253-006-0534-Z

6. S. K. Sharma, N. Sehgal and A. Kumar, Curr. Appl. Phys., 3 (2003) 307. doi: 10.1016/S1567-1739(02)00219-5

7. B. Taş, The Black Sea J. Sci., 1 (2011) 43. http://kfbd.giresun.edu.tr/fileadmin/user upl oad/2011 MART/4 Gaga Goelue Ordu Tuerkiye_Su_Kalitesinin_Incelenmesi.pdf

8. $\quad$ Ö. Özdestan and A. Üren, Academic Food J., 8 (2010) 35.

http://academicfoodjournal.com/archive/201 2/issue4/RP-11-18.pdf

9. L. Cui, T. Pu, Y. Liu and X. He, Electrochim. Acta, 88 (2013) 559. doi: 10.1016/j.electacta.2012.10.127 
10. J. S. Griesenbeck, M. D. Steck, J. C. Huber Jr, J. R. Sharkey, A. A. Rene and J. D. Brender, Nutr. J., 8 (2009) 1. doi: 10.1186/1475-2891-8-16

11. L. Fewtrell, Environ. Health Perspect., 112 (2004) 1371. doi/abs/10.1289/ehp.7216

12. M. Cemek, L. Akkaya, Y. O. Birdane, K. Seyrek, S. Bulut and M. Konuk, J. Food Compos. Anal., 20 (2007) 236. doi: 10.1016/j.jfca.2006.12.003

13. P. F. Swann, J. Sci. Food Agric., 26 (1975) 1615. doi: 10.1002/jsfa.2740261119

14. L. Zhou, J. P. Wang, L. Gai, D. J. Li and Y. B. Li, Sens. Actuators B Chem., 181 (2013) 65.

doi: 10.1016/j.snb.2013.02.041

15. S. K. Vaidya, C. Damodaran and K. K. Verma, Mikrochim. Acta, 106 (1992) 211. https://link.springer.com/article/10.1007/BF0 $\underline{1242092}$

16. A. Aydın, Ö. Ercan and S. Taşcıoğlu, Talanta, 66 (2005) 1181. doi:10.1016/j.talanta.2005.01.024

17. A. Afkhami, T. Madrakian and S. B. Aleseyyed, Clean-Soil Air Water, 40 (2012) 619.

doi: 10.1002/clen.201100273

18. Q. H. Liu, X. L. Yan, J. C. Guo, D. H. Wang, L. Li, F. Y. Yan and L. G. Chen, Spectrochim. Acta A, 73 (2009) 789.

doi: 10.1016/j.saa.2009.03.018

19. M. J. Ahmed, M. R. Haque, A. Ahsan, S. Siraj, M. H. R. Bhuiyan, S. C. Bhattacharjee and S. Islam, Pak. J. Environ. Chem., 11 (2010) 1.

http://pjaec.pk/index.php/pjaec/article/view/120

20. T. Zhang, H. Fan and Q. Jin, Talanta, 81 (2010) 95 .

doi: 10.1016/j.talanta.2009.11.042

21. H. Liu, G. Yang, E. S. Abdel-Halim and J. J. Zhu, Talanta, 104 (2013) 135.

doi: $10.1016 /$ j.talanta.2012.11.020

22. D. Connolly and B. Paull, Anal. Chim. Acta, 44 (2001) 53.

doi: 10.1016/S0003-2670(01)01068-6

23. M. R. Khan, S. M. Wabaidur, Z. A. Alothman, R. Busquets and M. Naushad, Talanta, 152 (2016) 513. doi: 10.1016/j.talanta.2016.02.036

24. S. Chamandust, M. R. Mehrasebi, K. Kamali, R. Solgi, J. Taran, F. Nazari and M. J. Hosseini, Int. J. Food Prop., 19 (2016) 1983. doi: 10.1080/10942912.2015.1091007

25. Z. H. Wen and T. F. Kang, Talanta, 62 (2004) 351. doi: 10.1016/i.talanta.2003.08.003

26. W. Dhaoui, M. Bouzitoun, H. Zarrouk, H. B. Ouada and A. Pron, Synth. Met., 158 (2008) 722. doi:10.1016/j.synthmet.2008.04.020

27. L. Li, D. Liu, K. Wang, H. Mao and T. You, Sens. Actuators B Chem., 252 (2017) 17. doi: 10.1016/j.snb.2017.05.155

28. J. M. Petroni, B. G. Lucca and V. S. Ferreira, Electroanalysis, 29 (2017) 1762. doi: 10.1002/elan.201700117

29. M. Sivakumar, M. Sakthivel, S. M. Chen, K. Pandi, T. W. Chen and M. C. Yu, Int. J. Electrochem. Sci., 12 (2017) 4835. doi: 10.20964/2017.06.24

30. J. Hu, F. Guo and L. Wang, Microchim. Acta, 184 (2017) 4637. doi: 10.1007/s00604-017-2500-0

31. M. Saber-Tehrani, A. Pourhabib, S. W. Husain and M. Arvand, Food Anal. Methods, 6 (2013) 1300. doi: $10.1007 / \mathrm{s} 12161-012-9543-\mathrm{y}$

32. Y. Haldorai, S. K. Hwang, A. I. Gopalan, Y. S. Huh, Y. K. Han, W. Voit, G. Sai-Anand and K. P. Lee, Biosens. Bioelectron., 79 (2016) 543. doi: 10.1016/j.bios.2015.12.054

33. F. Zhang, Y. Yuan, Y. Zheng, H. Wang, T. Liu and S. Hou, Microchim. Acta, 184 (2017) 1565. doi: 10.1007/s00604-017-2264-6

34. Z. Zhuang, H. Lin, X. Zhang F. Qiu and H. Yang, Microchim. Acta, 183 (2016) 2807. doi: 10.1007/s00604-016-1931-3

35. K. Lenghartova, L. Lauko, F. Cachob and E. Beinrohr, Acta Chim. Slov., 62 (2015) 152. doi: 10.17344/acsi.2014.838

36. Z. K. He, B. Fuhrmann and U. Spohn, Fresenius J. Anal. Chem., 367 (2000) 264. doi: $10.1007 / \mathrm{s} 002160000325$

37. J. Zhao, J. Wang, Y. Yang and Y. Lu, J. Chromatogr. Sci., 53 (2015) 1169. doi:10.1093/chromsci/bmu212 
38. M. Akyüz and Ş. Ata, Talanta, 79 (2009) 900.

doi: 10.1016/j.talanta.2009.05.016

39. Y. Zuo, C. Wang and T. Van, Talanta, 70 (2006) 281. doi: 10.1016/j.talanta.2006.02.034

40. Y. X. Guo, Q. F. Zhang, X. Shangguang and G. Zhen, Spectrochim. Acta A, 101 (2013) 107. doi: 10.1016/j.saa.2012.09.083

41. P. Poormoghadam, A. Larki and S. Rastegarzadeh, Anal. Methods, 7 (2015) 8655. doi: 10.1039/C5AY01812A

42. V. M. Ivanov, J. Anal. Chem., 59 (2004) 1002. https://link.springer.com/article/10.1023/B:J ANC.0000043920.77446.d7

43. V. V. Apyari, S. G. Dmitrienko, V. M. Ostrovskaya, E. K. Anaev and Y. A. Zolotov, Anal. Bioanal. Chem., 391 (2008) 1977. doi: 10.1007/s00216-008-2112-y

44. E. T. Steimle, E. A. Kaltenbacher and R. H. Byrne, Mar. Chem., 77 (2002) 255. doi: 10.1016/S0304-4203(02)00003-8

45. A. A. Ensafi and M. Amini, Sens. Actuators B Chem., 147 (2010) 61. doi: 10.1016/j.snb.2010.03.014

46. X. Huang, Y. Li, Y. Chen and L. Wang, Sens. Actuators B. Chem., 134 (2008) 780. doi: $10.1016 /$ j.snb.2008.06.028

47. A. A. Abdel Aziz, J. Lumin., 143 (2013) 663. doi: 10.1016/j.jlumin.2013.06.020

48. W. H. Chan, R. H. Yang and K. M. Wang, Anal. Chim. Acta, 444 (2001) 261. doi: 10.1016/S0003-2670(01)01106-0

49. A. Yari and F. Papi, Sens. Actuators B Chem., 138 (2009) 467. doi: 10.1016/j.snb.2009.02.011

50. A. A. Ensafi and A. Kazemzadeh, Microchem. J., 72 (2002) 193. doi: $10.1016 / \mathrm{S} 0026-265 X(02) 00035-8$

51. A. Kazemzadeh and S. Daghighi, Spectrochim. Acta A, 61 (2005) 1871. doi: 10.1016/j.saa.2004.06.057

52. W. Dhaoui, H. Zarrouk and A. Pron, Synth. Met., 157 (2007) 564. doi: 10.1016/j.synthmet.2007.06.004

53. L. F. Capitán-Vallvey, R. Avidad, M. D. Fernández-Ramos, A. Ariza-Avidad and E. Arroyo, Anal. Bioanal. Chem., 373 (2002) 289.

doi: $10.1007 / \mathrm{s} 00216-002-1320-0$
54. N. S. M. Noor, L. L. Tan, L. Y. Heng, K. F. Chong and S. N. Tajuddin, Food Chem., 207 (2016) 132. doi: 10.1016/j.foodchem.2016.03.088

55. A. Abdukayum and M. Tuerhong, Chinese J. Anal. Chem., 39 (2011) 564. doi: 10.3724/SP.J.1096.2011.00564

56. M. C. Blanco-López, M. J. Lobo-Castañón, A. J. Miranda-Ordieres and P. TuñónBlanco, Trends Anal. Chem., 23 (2004) 36. doi: 10.1016/S0165-9936(04)00102-5

57. P. Pradhan, R. J. Mascarenhas, T. Thomas, I. N. N. Namboothiri, O. J. D'Souza and Z. Mekhalif, J. Electroanal. Chem., 732 (2014) 30. doi: 10.1016/j.jelechem.2014.08.023

58. W. J. R. Santos, P. R. Lima, A. A. Tanaka, S. M. C. N. Tanaka and L. T. Kubota, Food Chem., 113 (2009) 1206. doi: 10.1016/j.foodchem.2008.08.009

59. H. R. Nassab, A. Souri, A. Javadian and M. K. Amini, Sens. Actuators B. Chem., 215 (2015) 360 . doi: 10.1016/j.snb.2015.03.086

60. B. Norouzi and M. Rajabi, J. Anal. Chem., 72 (2017) 897.

https://link.springer.com/article/10.1134\%2F S106193481708010X

61. B. B. Petković, D. Stanković, M. Milčić, S. P. Sovilj and D. Manojlović, Talanta, 132 (2015) 513. doi: 10.1016/j.talanta.2014.09.025

62. Y. Zhang, J. Yin, K. Wang, P. Chen and L. Ji, Appl. Polym. Sci., 128 (2013) 2971. doi: 10.1002/app.38466

63. W. M. Wang, J. Leng, Y. F. Yu, L. M. Lu, L. Bai and X. L. Qiu, Int. J. Electrochem. Sci., 9 (2014) 921.

http://www.electrochemsci.org/papers/vol9/9 0200921.pdf

64. D. Gligor and A. Walcarius, J. Solid State Electrochem., 18 (2014) 1519. doi: 10.1007/s10008-013-2365-Z

65. Z. W. Peng, D. Yuan, Z. W. Jiang and Y. F. Li, Electrochim. Acta, 238 (2017) 1. doi: 10.1016/j.electacta.2017.03.121

66. C. H. Yang, Q. $\mathrm{Lu}$ and S. S. Hu, Electroanalysis, 18 (2006) 2188. doi: 10.1002/elan.200603646 